\title{
PEMANFAATAN SUMBER BELAJAR DALAM PENGEMBANGAN KARAKTER PESERTA DIDIK
}

(Studi Multisitus di MI Nurul Islam Mirigambar

dan MI Hidayatul Mubtadi' in Wates Sumbergempol Tulungagung)

\section{Mega Dwi Susanti ${ }^{1}$}

Email: khalishtaathira@gmail.com

\begin{abstract}
Primary education can build the students' character through many kinds of learning sources. Learning sources is anything which can be used to optimalize the result of the study. It can be seen not only from the result but also the process of students' interaction with many kinds of learning sources which can motivate them to study and increase their understanding in a certain lesson. The use of learning sources can be used as one of ways in developing the students' character. There are several ways in using learning sources in MI Nurul Islam Mirigambar and MI Hidayatul Mubtadiin Wates Sumbergempol Tulungagung.

The focus of this thesis are (1) How to choose the use of learning sources in developing the students' character in MI Nurul Islam Mirigambar and MI Hidayatul Mubtadiin Wates Sumbergempol Tulungagung (2) How is the process in using learning sources in MI Nurul Islam Mirigambar and MI Hidayatul Mubtadiin Wates Sumbergempol Tulungagung (3) How is the result of using learning sources in MI Nurul Islam Mirigambar and MI Hidayatul Mubtadiin Wates Sumbergempol Tulungagung.

The purpose of this study are to explain and describe (1) To know the way in choosing the use of learning sources in developing students' character in MI Nurul Islam Mirigambar and MI Hidayatul Mubtadiin Wates Sumbergempol Tulungagungs (2) To know the process in using learning sources in developing the students' character in MI Nurul Islam Mirigambar and MI Hidayatul Mubtadiin Wates Sumbergempol Tulungagung (3) To know the result of using learning sources in developing the students' character in MI Nurul Islam Mirigambar and MI Hidayatul Mubtadiin Wates Sumbergempol Tulungagung.

The method of this study is using qualitative study that is multisite. The locations are in MI Nurul Islam Mirigambar and MI Hidayatul Mubtadiin Wates Sumbergempol Tulungagung. The data sources of this study are informant, event,
\end{abstract}

${ }^{1}$ Dosen Tetap Fakultas Tarbiyah Sekolah Tinggi Ilmu Syari'ah Faqih Asy'ari Kediri 
location and document. The kinds of data are primary and secondary data. The technique of this study are individual site data and analysis and multisite data analysis while the data validation uses, credibility, dependability, transferability and information.

From this study, the writer can conclude: (1) the way in choosing learning sources to develop the students' character in MI Nurul Islam Mirigambar and MI Hidayatul Mubtadiin Wates Sumbergempol Tulungagung is very comprehensive. It covers adaptation of students' character application and the environment (2) the process of using learning sources in developing students' character in MI Nurul Islam Mirigambar has integrated in school regulation and then it's socialized and implemented the schedule orderly along with organizer team and in MI Hidayatul Mubtadiin Wates Sumbergempol Tulungagung implement it through application which can be separated into several kinds, they are daily routine and organizing (3) the result of using learning sources in developing students' character in MI Nurul Islam Mirigambar can be devided into religious character, discipline, caring to environment, responsible, creative, loving reading and standing alone, white in MI Hidayatul Mubtadiin Wates Sumbergempol Tulungagung covers religious character, discipline, responsible, friendly, communicative, standing alone and honest.

Keywords: Learning Sources, the Central of Learning Sources, Character Education

\section{Pendahuluan}

Pendidikan merupakan salah satu sektor penting dalam pembangunan di setiap negara. Menurut Undang-Undang No. 20 Tahun 2003 tentang Sisdiknas dalam pasal 1 disebutkan bahwa pendidikan merupakan usaha sadar dan terencana untuk mewujudkan suasana belajar dan proses pembelajaran agar peserta didik secara aktif mengembangkan potensi dirinya untuk memiliki kekuatan spiritual keagamaan, pengendalian diri, kepribadian, kecerdasan, akhlak mulia, serta keterampilan yang diperlukan dirinya, masyarakat, mengembangkan segala potensi yang dimiliki peserta didik melalui proses pembelajaran. ${ }^{2}$

Pembelajaran pada hakikatnya merupakan proses interaksi antara guru dengan peserta didik, baik interaksi secara langsung seperti kegiatan tatap muka, maupun secara tidak langsung yaitu dengan menggunakan berbagai media dan lingkungan. Dalam usaha meningkatkan kualitas proses pembelajaran dan hasil pembelajaran, kita

\footnotetext{
${ }^{2}$ Redaksi Sinar Grafika, Undang-undang Sistem Pendidikan Nasional Nomor 20 Tahun 2013

(Bandung: Sinar Grafika, 2009), h. 2.
}

Jurnal Dirasah, Volume 1, Nomor 1, Februari 2018 
tidak boleh melupakan satu hal yang sudah pasti kebenarannya yaitu bahwa peserta didik harus banyak berinteraksi dengan sumber belajar. Tanpa sumber belajar yang memadai sulit diwujudkan proses pembelajaran yang mengarah kepada tercapainya hasil belajar yang optimal.

Sumber belajar adalah segala sesuatu yang ada di sekitar lingkungan kegiatan belajar yang secara fungsional dapat digunakan untuk membantu optimalisasi hasil belajar. Optimali hasil belajar ini dapat dilihat tidak hanya dari hasil belajar (output) namun juga dilihat dari proses berupa interaksi siswa dengan berbagai macam sumber yang dapat merangsang siswa untuk belajar dan mempercepat pemahaman dan penguasaan bidang ilmu yang dipelajarinya. ${ }^{3}$

Pengembangan karakter dapat dimaknai sebagai pendidikan nilai, pendidikan moral, pendidikan budi pekerti, pendidikan watak yang bertujuan mengembangkan kemampuan peserta didik untuk dapat memberikan keputusan baik-buruk, memelihara apa yang baik, dan mewujudkan kebaikan itu dalam kehidupan seharihari dengan sepenuh hati.

Penelitian ini tentunya lebih unggul dari pada penelitian sebelumya karena dari penelitian ini tidak terfokuskan pada satu karakter saja yang diteliti melainkan berbagai macam karakter yang ada pada peserta didik di masing-masing lembaga madrasah tersebut yaitu MI Nurul Islam Mirigambar dan Mi Hidayatul Mubtadiin wates Sumbergempol Tulungagung.

Atas dasar fenomena tersebut maka peneliti merasa tertarik untuk melakukan penelitian dengan judul "Pemanfaatan Sumber Belajar dalam Pengembangan Karakter Peserta Didik." Dalam penelitian ini, peneliti fokus pemanfaatan sumber belajar dalam pengembangan karakter peserta didik, yang meliputi proses, macam/bentuk, hasil pemanfaatan pusat sumber belajar dalam pengembangan karakter peserta didik yang ada di MI Nurul Islam Mirigambar dan MI Hidayatul Mubtadiin Wates Sumbergempol.

\section{Metode Sistematika Pembahasan}

\section{- Rancangan penelitian}

Pendekatan yang digunakan adalah pendekatan kualitatif, yaitu penelitian yang dilakukan untuk menghasilkan data diskriptif baik berupa tulisan maupun lisan serta perilaku dari subyek yang diamati. Bogdan dan Tailor seperti yang dikutip oleh Moleong mendefinisikannya sebagai prosedur penelitian yang

\footnotetext{
${ }^{3}$ Wina Sanjaya, Perencanaan dan Desain Sistem Pembelajaran (Jakarta: Kencana, 2009), h. 288.
} 
menghasilkan data deskriptif berupa kata-kata tertulis atau lisan dari orang-orang dan perilaku yang diamati". 4

- Kehadiran Peneliti

Untuk memperoleh data sebanyak mungkin, detail dan juga orisinil maka selama penelitian di lapangan, peneliti sendiri atau dengan bantuan orang lain merupakan alat atau instrumen pengumpul data utama. Dalam penelitian ini, peneliti bertindak sebagai instrument sekaligus pengumpul data, karena dalam penelitian kualitatif instrumen utamanya adalah manusia. ${ }^{5}$

- Lokasi Penelitian

Lokasi penelitian yang dipilih oleh peneliti adalah MI Nurul Islam dan MI Hidayatul Mubtadiin berada di bagian selatan kecamatan Sumbergempol kabupaten Tulungagung, tepatnya MI Nurul Islam di Desa Mirigambar MI Hidayatul Mubtadiin di desa Wates, yang semuanya masuk dalam wilayah kecamatan Sumbergempol kabupaten Tulungagung yang keberadaanya sangat strategis.

\section{- Sumber Data}

Sumber data adalah "subjek dari mana data diperoleh". Sumber data diidentifikasikan menjadi 3 yaitu person, place, dan paper. ${ }^{6}$ Person yaitu sumber data berupa orang yang bisa memberikan data berupa jawaban lisan melalui wawancara. Dalam penelitian ini personnya adalah kepala sekolah, wakil kepala sekolah dan guru di Sekolah Dasar Kecamatan Sumbergempol Tulungagung. Place yaitu sumber data berupa tempat atau sumber data yang menyajikan tampilan berupa keadaan diam dan bergerak, meliputi fasilitas gedung, kondisi lokasi, kegiatan belajar mengajar, kinerja aktifitas dan sebagainya yang ada di Sekolah Dasar Kecamatan Sumbergempol Tulungagung. Paper yaitu data berupa simbol atau sumber data yang menyajikan tanda berupa huruf, angka, gambar, simbolsimbol dan lain-lain. Dalam penelitian ini papernya adalah berupa benda-benda tertulis seperti buku-buku arsip, catatan-catatan, dokumen yang ada di Sekolah Dasar Kecamatan Sumbergempol Tulungagung.

- Teknik Pengumpulan Data

\footnotetext{
${ }^{4}$ Lexy J. Moleong, Metodologi Penelitian Kualitatif, (Bandung: Remaja Rosda Karya, 2002), h. 3.

${ }^{5}$ Rochiati Wiriaatmaja, Metode Penelitian Tindakan Kelas, (Bandung: PT. Rosdakarya, 2007), h. 96.

${ }^{6}$ Suharsimi Arikunto, Prosedur Penelitian, Suatu Pendekatan Praktek, (Jakarta: Rineka Cipta,1993), h.102.
} 
Sesuai dengan jenis penelitian diatas adalah kualitatif, maka cara pengumpulan data dilakukan dengan empat teknik yaitu: wawancara, observasi, catatan lapangan, dokumentasi.

- Teknik Analisis Data

Analisis data merupakan proses mencari dan mengatur secara sistematik hasil observasi, transkrip wawancara, catatan lapangan dan bahan-bahan lain yang telah dihimpun untuk meningkatkan pemahaman peneliti tentang kasus yang diteliti yang dilanjutkan dengan pencarian makna untuk dilaporkan, sedangkan Huberman dan Miles mengemukakan bahwa analisis data penelitian kualitatif merupakan proses penelaahan, pengerutan dan pengelompokan data dengan tujuan untuk menyusun hipotesis kerja dan mengangkatnya menjadi teori hasil penelitian. ${ }^{7}$

Penelitian ini menggunakan studi multisitus di dua situs berbeda yakni MI Nurul Islam Mirigambar dan MI Hidayatul Mubtadiin Wates Analisis data lintas situs dimaksudkan sebagai proses membandingkan temuan-temuan yang diperoleh dari tiap-tiap situs, sekaligus sebagai proses memadukan antar situs. Temuan yang diperoleh dari MI Nurul Islam Mirigambar disusun kategori dan tema, dianalisis dan dibuat penjelasan naratif yang selanjutnya dikembangkan menjadi teori substantif I.

Teori substantif I dianalisis dengan teori substantif II (temuan di MI Hidayatul Mubtadiin Wates) untuk menemukan perbedaan karakteristik masing-masing kasus sebagai konsepsi teoritis berdasarkan perbedaan. Selanjutnya dilakukan analisis lintas situs antara situs I dan situs II dengan cara yang sama. Analisis akhir ini dimaksudkan untuk menyusun konsepsi sistematis berdasarkan analisis data dan interpretasi teoritis yang selanjutnya dijadikan bahan untuk mengembangkan temuan teori substantif.

\section{- Pengecekan Keabsahan Data}

Pengecekan atau pemeriksaan diperlukan untuk menjamin keabsahan data. pemeriksaan data menganut teknik tertentu yang dipandang sesuai dengan model penelitian yang dilakukan. Pengecekan keabsahan data dilakukan dengan empat langkah, yaitu uji kredibilitas, uji transferability, uji dependability, dan uji confirmability.

Pertama, uji kredibilitas data melalui triangulasi, perpanjangan kehadiran/ pengamatan, peningkatan ketekunan, diskusi sejawat, dan review informan. Triangulasi diartikan sebagai pengecekan data dari berbagai sumber dengan berbagai cara, dan berbagai waktu. Ada tiga macam triangulasi, yaitu triangulasi

\footnotetext{
7 A. Michael Huberman and B. Miles mathew, Qualitatif Data Analisis, Edisi Bahasa Indonesia (Jakarta:UI Press, 1992), h. 14.
} 
sumber, triangulasi teknik, dan triangulasi waktu. Triangulasi sumber dilakukan dengan cara mengecek data yang telah diperoleh melalui berbagai sumber. Triangulasi teknik dilakukan dengan cara mengecek data kepada sumber yang sama dengan teknik berbeda. Sedangkan triangulasi waktu dilakukan dengan cara melakukan pengecekan dengan wawancara, observasi atau teknik lain dalam waktu atau situasi yang berbeda. ${ }^{8}$ Dalam penelitian ini peneliti menggunakan trianggulasi sumber, yaitu dengan wawancara beberapa sumber yang berbeda, yaitu kepala sekolah, wakil kepala bagian humas, dan guru madrasah.

Kedua, ujitransferability dengan menyusun laporan penelitian ini dengan jelas, terperinci, sistematis dan dapat dipercaya, sehingga pembaca menjadi jelas atas hasil penelitian tersebut sehingga hasil penelitian ini bisa diberlakukan di tempat lain manakala karakter di tempat lain itu sama dengan karakter obyek penelitian ini ada kemiripan.

Ketiga, uji dependability yang dilakukan oleh ahli yaitu Dr. Chusnul Chotimah, M.Ag. dan Dr. Nur Efendi, M.Ag untuk meminimalisir kesalahankesalahan hasil penelitian.

Keempat, uji confirmability dilakukan dengan cara mengkonfirmasikan hasil penelitian ini kepada para informan dan penguji. Hasil penelitian ini telah memenuhi standar confirmability karena telah dipertahankan di depan para penguji melalui ujian seminar hasil, ujian tertutup dan ujian terbuka.

Ketekunan pengamatan dilakukan dengan cara peneliti mengadakan pengamatan secara teliti dan cermat, serta berkesinambungan. Dengan cara seperti ini maka kepastian data dari urutan peristiwa akan dapat direkam secara pasti dan sistematis. ${ }^{9}$ Untuk mendukung cara ini, peneliti banyak membaca referensi buku maupun hasil penelitian atau dokumentasi-dokumentasi yang terkait dengan temuan yang diteliti. Dengan membaca ini maka diharapkan wawasan peneliti akan semakin luas dan tajam, sehingga dapat digunakan untuk memeriksa data yang ditemukan itu benar atau terpercaya atau tidak.

\footnotetext{
${ }^{8}$ Ibid., h. 273-274.

${ }^{9}$ Sugiyono, Metode., h. 272.
} 


\section{Hasil Penelitian}

\section{Temuan di Situs 1 MI Nurul Islam}

- Temuan yang berkaitan dengan fokus pertama yaitu mengenai cara memilih macam pemanfaatan sumber belajar dalam pengembangan karakter peserta didik di MI Nurul Islam

Berdasarkan cara memilih pemanfaatan sumber belajar drumband dan adiwiyata melihat dari karakter peserta didik dan lingkungan sekitar. Musik bermanfaat sebagai pengembangan kecerdasan peserta didik, namun musik juga memiliki manfaat lain. Selain berpengaruh untuk perkembangan peserta didik, musik juga bermanfaat untuk meningkatkan perkembangan pribadi dan sosial peserta didik. Pembelajaran dengan musik bisa membuat peserta didik mengembangkan hubungan emosional dengan lingkungan sosial peserta didik.

Begitu pula dengan kegiatan adiwiyata yang diprogramkan MI Nurul Islam. Dengan sekolah adiwiyata peserta didik diajari peduli lingkungan dan saling bekerja sama untuk menjaga kelestarian lingkungan. Adiwiyata ini dipilih supaya peserta didik mengerti akan pentingnya penghijauan bagi bumi kita.

- Temuan yang berkaitan dengan fokus kedua yaitu mengenai proses pemanfaatan sumber belajar dalam pengembangan karakter peserta didik di MI Nurul Islam

Proses pemanfaatan sumber belajar sudah terintegrasikan dalam peraturanperaturan yang telah dibuat oleh lembaga sekolah. Pendidikan karakter juga dilaksanakan melalui pengembangan diri seperti Pramuka dan drumband. Pendidikan karakter dalam budaya madrasah juga telah ditetapkan shalat dhuhur berjamaah, kegiatan istighosah, pondok Ramadhan, adiwiyata, senam, dan upacara. Dari hasil pemilihan program yang dipilih tersebut, kemudian akan di sosialisasikan kepada seluruh guru dan pengurus beserta wali murid. Dengan masing-masing jadwal kegiatan sudah ditetapkan pada awal perencanaan persetujuan sumber belajar yang akan digunakan serta dibentuknya tim untuk penggerak setiap kegiatan.

- Temuan yang berkaitan dengan fokus ketiga yaitu mengenai pemanfaatan sumber belajar sumber belajar dalam pengembangan karakter peserta didik di MI Nurul Islam

Hasil pemanfaatan sumber belajar di MI Nurul Islam akan terlihat manakala dilaksanakan dalam setiap kegiatan mulai dari pembelajaran, saat anak terlibat dalam pengembangan diri, dan ketika anak berada dalam budaya madrasah, namun penilaian itu belum tersusun dengan baik. 


\section{Temuan Penelitian di Situs 2 MI HIdayatul Mubtadiin Wates}

- Temuan yang berkaitan dengan fokus pertama yaitu mengenai cara memilih macam pemanfaatan sumber belajar dalam pengembangan karakter peserta didik di MI Hidayatul Mubtadiin Wates.

Berdasarkan cara memilih pemanfaatan sumber belajar di MI Hidayatul Mubtadiin dari pembiasaan yang ditanamkan di lembaga madrasah yang menjadi sorotan untuk pengembangan karakter peserta didik. Finger Print dilakukan untuk mengembangkan kedisplinan untuk datang ke sekolah dan membudayakan hidup rukun dan mengantri, secara tidak langsung itu semua sudah melatih kesabaran peserta didik.

Begitu pula dengan kegiatan PKS (Patroli Keamanan Sekolah) yang diprogramkan MI Hidayatul Mubtadiin Wates. Melihat dari posisi sekolah berada di jalan jalur besar dengan kendaraan yang sangat rame setiap harinya, maka dengan alasan itu peserta didik di ajari bagaimana cara berlalu lintas yang baik ketika di jalan, kegiatan ini juga sangat membantu antar teman dan guru.

- Temuan yang berkaitan dengan fokus kedua yaitu mengenai proses pemanfaatan sumber belajar dalam pengembangan karakter peserta didik di MI Hidayatul Mubtadiin.

Proses pemanfaatan sumber belajar sudah terintegrasikan dalam peraturanperaturan yang telah dibuat oleh lembaga sekolah. Pendidikan karakter telah di integrasikan dalam pembelajaran yakni tertuang dalam budaya sekolah yang meliputi pembisaan dan pengkondisian lingkungan sekitar.

Pemanfaatan sumber belajar dalam pengembangan karakter juga dilaksanakan melalui pengembangan diri seperti Pramuka dan drumband, PKS, Finger print. Pendidikan karakter dalam budaya madrasah juga telah ditetapkan shalat dhuhur berjamaah, piket kebersihan dan senam.

- Temuan yang berkaitan dengan fokus ketiga yaitu mengenai pemanfaatan sumber belajar sumber belajar dalam pengembangan karakter peserta didik di MI Hidayatul Mubtadiin Wates.

Hasil pemanfaatan sumber belajar di MI Hidayatul Mubtadiin Wates. dilaksanakan dalam setiap kegiatan mulai dari pembelajaran, saat anak terlibat dalam pengembangan diri, dan ketika anak berada dalam budaya madrasah.

Dari beberapa karakter yang telah tumbuh di MI Hidayatul Mubtadiin Wates evaluasi seluruh karakter yang muncul sekarang ini antara lain: Religius, Disiplin, Tanggung jawab, bersahabat dan komunikatif, mandiri, jujur dari sini 
dapat membuktikan bahwa pemanfaatan sumber belajar dalam pengembangan karakter di madrasah ini telah berjalan dengan baik.

\section{Temuan lintas situs}

Untuk mempermudah dalam proses analisis lintas situs temuan dalam penelitian ini maka dapat disajikan dalam tabel berikut;

Tabel Komparasi Temuan Lintas Situs

\begin{tabular}{lllll}
\hline No & Fokus Penelitian & Situs MI NURIS & \multicolumn{1}{c}{ Situs MI HM } & \multicolumn{1}{c}{ Keterangan } \\
\hline 1 & Cara memilih & Agar pengadaan & Berdasarkan cara memilih & Agar pembelajaran \\
& pemanfatan & program dapat & pemanfaatan sumber & berjalan maksimal \\
& sumber belajar & terlaksana dengan & belajar di MI Hidayatul & sesuai dengan \\
& dalam & baik dan sesuai & Mubtadiin dari pembiasaan & harapan maka \\
pengembangan & dengan keadaan yang & yang ditanamkan di & diperlukan cara \\
karakter peserta & ada di lembaga & lembaga madrasah yang & memilih sumber \\
didik & madrasah tersebut. & menjadi sorotan untuk & belajar dengan \\
& Berdasarkan cara & pengembangan karakter & melihat karakter \\
& memilih pemanfaatan & peserta didik dan & peserta didik, \\
& sumber belajar & lingkungan sekitar. & lingkungan sekitar \\
& melihat dari karakter & & dan melakukan \\
& peserta didik dan & & pembiasaan dalam \\
& lingkungan sekitar. & & budaya madrasah.
\end{tabular}




\begin{tabular}{|c|c|c|c|c|}
\hline 2 & $\begin{array}{l}\text { Proses } \\
\text { pemanfaatan } \\
\text { Sumber Belajar } \\
\text { dalam } \\
\text { Pengembangan } \\
\text { Karakter Peserta } \\
\text { didik. }\end{array}$ & $\begin{array}{l}\text { Pemanfaatan sumber } \\
\text { belajar yang } \\
\text { terintegrasi kemudian } \\
\text { disosialisasikan dan } \\
\text { melaksanakan jadwal } \\
\text { kegiatan dengan } \\
\text { tertib serta } \\
\text { dibentuknya tim } \\
\text { penggerak kegiatan. }\end{array}$ & $\begin{array}{l}\text { - Pembiasaan terdiri dari } \\
\text { beberapa jenis yaitu } \\
\text { bersifat pengkondisian, } \\
\text { rutinitas, spontanitas dan } \\
\text { keteladanan. } \\
\text { - Pengkondisian adalah } \\
\text { mengkondisi peserta } \\
\text { didik dalam lingkungan } \\
\text { sekolah baik dari } \\
\text { kebersihan diri dan } \\
\text { lingkungan sekolah. } \\
\text { - Rutinitas adalah } \\
\text { malakukan kegiatan } \\
\text { dengan rutin atau } \\
\text { kegiatan yang dilakukan } \\
\text { terus menerus. } \\
\text { - Spontanitas adalah } \\
\text { kegiatan yang dilakukan } \\
\text { dengan tiba-tiba. } \\
\text { - Keteladanan adalah } \\
\text { sikap dan perilaku guru } \\
\text { sebagai cermin peserta } \\
\text { didik }\end{array}$ & $\begin{array}{l}\text { Pemanfaatan sumber } \\
\text { belajar akan berhasil } \\
\text { manakala } \\
\text { disosialisasikan } \\
\text { dengan warga } \\
\text { sekolah dan } \\
\text { melakukan } \\
\text { penjadwalan dan dan } \\
\text { adanya tim } \\
\text { penggerak kegiatan. } \\
\text { - Pemanfaatan sumber } \\
\text { belajar dalam } \\
\text { pengembangan } \\
\text { karakter peserta } \\
\text { didik akan berhasil } \\
\text { manakala dilakukan } \\
\text { - dengan } \\
\text { pengkondisian, } \\
\text { rutinitas, spontanitas } \\
\text { dan keteladanan. }\end{array}$ \\
\hline 3 & $\begin{array}{l}\text { Hasil } \\
\text { pemanfaatan } \\
\text { Sumber Belajar } \\
\text { dalam } \\
\text { Pengembangan } \\
\text { Karakter Peserta } \\
\text { didik. }\end{array}$ & $\begin{array}{l}\text { Pemanfaatan sumber } \\
\text { belajar dalam } \\
\text { pengembangan } \\
\text { peserta didik yang } \\
\text { ada disekolah ini } \\
\text { antara lain: } \\
\text { Religius, Disiplin, } \\
\text { Peduli lingkungan } \\
\text { Tanggung jawab } \\
\text { Mandiri, Gemar } \\
\text { membaca, Kreatif }\end{array}$ & $\begin{array}{l}\text { Pemanfaatan sumber } \\
\text { belajar dalam } \\
\text { pengembangan peserta } \\
\text { didik yang ada disekolah } \\
\text { ini antara lain: Religius, } \\
\text { Disiplin, Tanggung jawab, } \\
\text { Bersahabat dan } \\
\text { komunikatif, Mandiri dan } \\
\text { Jujur }\end{array}$ & $\begin{array}{l}\text { - Hasil pemanfaatan } \\
\text { sumber belajar akan } \\
\text { terlihat manakala } \\
\text { dilaksanakan dengan } \\
\text { rutin dalam setiap } \\
\text { kegiatan mulai dari } \\
\text { pembelajaran, saat } \\
\text { anak terlibat dalam } \\
\text { pengembangan diri, } \\
\text { dan ketika anak } \\
\text { berada dalam } \\
\text { lingkungan } \\
\text { madrasah. }\end{array}$ \\
\hline
\end{tabular}




\section{Proposisi lintas situs}

Berdasarkan analisis temuan penelitian lintas situs diatas, maka dapat ditarik proposisi sebagai berikut:

- Proposisi I:

Agar pembelajaran berjalan maksimal sesuai dengan harapan maka diperlukan cara memilih sumber belajar dengan melihat karakter peserta didik, lingkungan sekitar dan melakukan pembiasaan dalam budaya madrasah.

- Proposisi II:

Pemanfaatan sumber belajar akan berhasil manakala disosialisasikan dengan warga sekolah dan melakukan penjadwalan dan adanya tim penggerak kegiatan.

Pemanfaatan sumber belajar dalam pengembangan karakter peserta didik akan berhasil manakala dilakukan dengan pengkondisian, rutinitas, spontanitas dan keteladanan.

- Proposisi III:

Hasil pemanfaatan sumber belajar akan terlihat manakala dilaksanakan dengan rutin dalam setiap kegiatan mulai dari pembelajaran, saat anak terlibat dalam pengembangan diri, dan ketika anak berada dalam lingkungan madrasah.

\section{Pembahasan}

\section{Cara Memilih Sumber Belajar dalam Pengembangan Karakter Peserta didik}

Dalam setiap program pembelajaran, sekolah harus memilih sumber belajar yang tepat artinya sumber belajar harus sesuai dengan lingkungan sekitar dan karakter peserta didik. Sumber belajar harus terprogram dan terstruktur dengan rapi agar pemanfaatan sumber belajar dalam pengembangan karakter peserta didik berjalan dengan efektif dan sesuai dengan tujuan yang diharapkan.

Cara memilih sumber belajar di MI Nurul Islam dengan tahap awal yang harus dilalui, memilihkan sumber belajar yang menyesuaikan dengan karakter peserta didik dan menyesuaikan pemanfaatan sumber belajarnya supaya terarah dan bisa berjalan sesuai harapan. Karakter peserta didik di MI Nurul Islam Mirigambar riang tidak suka diam tapi tetap sopan, baik putra putrinya suka dan antusias mengikuti segala kegiatan yang di programkan, semangatnya juga sangat tinggi.

Program di MI Nurul Islam Mirigambar dan MI Hidayatul Mubtadiin Wates Sumbergempol Tulungagung memilih sumber belajar dengan melihat lingkungan sekitar sebagai acuan pemanfaatan sumber belajar yang akan digunakan. Lingkungan Sekitar (setting), yaitu situasi di sekitar proses belajar-mengajar terjadi. Latar atau lingkungan ini dibedakan menjadi dua macam yaitu lingkungan fisik dan non fisik. 
Lingkungan fisik seperti gedung, sekolah, perpustakaan, laboratorium, rumah, studio, ruang rapat, musium, taman dan sebagainya. Sedangkan lingkungan non fisik contohnya adalah tatanan ruang belajar, sistem ventilasi, tingkat kegaduhan lingkungan belajar, cuaca dan sebagainya. ${ }^{10}$

Sejalan dengan pendapat Dalyono bahwa, keadaan sekolah tempat turut mempengaruhi tingkat keberhasilan belajar. kualitas guru, metode mengajarnya, kesesuaian kurikulum dengan kemampuan anak, keadaan fasilitas atau perlengkapan di sekolah, pelaksanaan tata tertib sekolah, dan sebagainya, semua ini turut mempengaruhi keberhasilan anak. ${ }^{11}$

Lingkungan sekitar memiliki pengaruh yang sangat penting terhadap perkembangan karakter peserta didik Lingkungan yang berada disekitar kita dapat dijadikan sebagai sumber belajar.

Kemudian tahapan selanjutnya di MI Hidayatul Mubtadiin Wates Sumbergempol Tulungagung yaitu cara memilih pemanfaatan sumber belajar membuat tim yang teridi dari kepala sekolah, para dewan guru, tokoh pendidikan, wakil dari yayasan. Program itu telah dibuat dalam rangkaian rencana kerja madrasah yang telah ditetapkan dalam tahun-tahun sebelumnya. Masukan, saran, serta berbagai pertimbangan berkaitan dengan pemanfaatan sumber belajar akan kami tampung, terus akan kami saring, termasuk mencari hambatan dan peluang, yang pada akhirnya kami akan membuat kesimpulan mulai dari beban, muatan sumber belajar yang akan ditetapkaan dalam program tersebut.

Tahapan akhir yaitu sosialisasi program madrasah dilaksanakan sebelum tahun pelajaran baru dimulai, kegiatan ini merupakan kegiatan yang rutin dilakukan karena telah menjadi program madrasah, yang dituliskan dalam program tahunan madrasah. Sosialisi program merupakan kepentingan bersama stake holder madrasah, Karena semua program tidak akan bisa berjalan dengan baik tanpa dukungan dari semua stake holder yang ada, dan masyarakat lingkungan madrasah. Program madrasah disosialisasikan pada saat pertemuan dengan wali siswa, rapat komite, dan rapat dengan yayasan. Rapat dengan wali siswa biasanya dilakukan pada saat awal tahun ajaran baru.

Menurut Abdullah Nasih Ulwan, pendidikan dengan proses pembiasaan merupakan cara yang sangat efektif dalam membentuk iman, akhlak mulia,

\footnotetext{
${ }^{10}$ Sudjarwo, Bebererapa Aspek Pengembangan Sumber Belajar, (Jakarta: PT Mediyatama Sarana Perkasa, 1989), h. 142.

${ }^{11}$ Dalyono, Psikologi Pendidikan, (Jakarta: Rineka Cipta, 2009), h. 59.
} 
keutamaan jiwa dan untuk melakukan syariat yang lurus. ${ }^{12}$ Pembiasaan merupakan proses penanaman kebiasaan, mengupayakan suatu tindakan agar terbiasa melakukannya, sehingga terkadang seseorang tidak menyadari apa yang dilakukannya karena sudah menjadi kebiasaan. Jadi, teori pembiasaan dalam pendidikan adalah yang proses pendidikan yang berlangsung dengan jalan membiasakan peserta didik untuk bertingkah laku, berbicara, berpikir dan melakukan aktivitas tertentu menurut kebiasaan yang baik, sebab tidak semua hal yang dapat dilakukan itu baik.

Karena di MI Nurul Islam Mirigambar dan Mi Hidayatul Mubatdiin Wates Sumbergempol Tulungagung memiliki cara memilih sumber belajar yang menyeluruh artinya cara memilih pemanfaatan sumber belajar sudah terencana dan terstruktur rapi agar pemanfaatan sumber belajar yang dilakukan berjalan dengan efektik dan sesuai dengan tujuan yang diharapakan, maka kami sebut cara memilih pemanfaatan sumbe belajar dalam pengembangan karakter peserta didik ini sangat komprehensif.

Cece Wijaya dan A.Thabrani Rusyah, berpendapat bahwa sumber belajar adalah lingkungan yang dapat dimanfaatkan oleh sekolah sebagai sumber pengetahuan, dapat berupa manusia atau bukan manusia. ${ }^{13}$ Menurut pendapat ahli lain dikemukakan oleh, Ahmad Rohani dan Abu Ahmadi menguraikan bahwa sumber belajar adalah segala daya yang dapat dipergunakan untuk kepentingan proses atau aktifitas pengajaran baik secara langsung maupun tidak langsung diluar dari peserta didik (lingkungan) yang melengkapi diri mereka pada saat pengajaran berlangsung. ${ }^{14}$ Dan dipertegas pendapat lain juga dikemukakan oleh, Nana Sujana \& Ahmad Rivai, memberikan pengertian sumber belajar adalah segela daya yang dapat dimanfaatkan guna memberikan kemudahan kepada seseorang dalam belajarnya. ${ }^{15}$ Kriteria pemilihan sumber belajar yang perlu diperhatikan adalah sebagai berikut:

- Tujuan yang ingin dicapai, ada sejumlah tujuan yang ingin dicapai, dengan menggunakan sumber belajar dipergunakan untuk menimbulkan motivasi, untuk keperluan pengajaran, untuk keperluan penelitian ataukah untuk pemecahan masalah. Harus disadari bahwa masing-masing sumber belajar memiliki kelebihan dan kelemahan.

\footnotetext{
${ }^{12}$ Abdulloh Nasih Ulwan. Belajar dan Pembelajaran. (Jakarta: Rineka Cipta, 2005), h. 31

${ }^{13}$ Cece Wijaya dan A. Thabrani Rusyah, Kemampuan Dasar Guru dalam proses BelajarMengajar, (Bandung: Rosda Karya, 1994), h. 138.
${ }^{14}$ Ahmad Rohani dan Abu Ahmadi, Pengelolaan Pengajaran (Jakarta: Rineka Cipta, 1991), h. 152.
${ }^{15}$ Nana Sudjana, Teknologi Pengajaran, (Bandung: Sinar Baru: 1989), h. 76


- Ekonomis, sumber belajar yang dipilih harus murah. Kemurahan di sini harus diperhitungkan dengan jumlah pemakai, lama pemakaian, langka tidaknya peristiwa itu terjadi dan akurat tidaknya pesan yang disampaikan.

- Praktis dan sederhana, sumber belajar yang sederhana, tidak memerlukan peralatan khusus, tidak mahal harganya, dan tidak membutuhan tenaga terampil yang khusus.

- Gampang didapat, sumber belajar yang baik adalah yang ada di sekitar kita dan mudah untuk mendapatkannya.

- Fleksibel atau luwes, sumber belajar yang baik adalah sumber belajar yang dapat dimanfaatkan dalam berbagai kondisi dan situasi. $^{16}$

\section{Proses pemanfaatan sumber belajar dalam pengembangan karakter peserta didik}

Di MI Nurul Islam Mirigambar Sumbergempol Tulungagung dalam proses pemanfaatan sumber belajar dalam pengembangan karakter peserta didik yang dilakukan pertama kali adalah mengadakan sosialisali. Melaksanakan sosialisasi dan melakukan komitmen bersama antara seluruh komponen warga madrasah/stakeholder kemudian, membuat komitmen dengan semua stakeholder (seluruh warga sekolah, orang tua siswa, komite, dan tokoh masyarakat setempat) untuk mendukung pemanfaatan sumber belajar dalam pengembanngan karakter. Langkah selanjutnya membentuk tim penanggung jawab kegiatan dan menjadwalkan, kegiatan tersubut akan dilakukan.

Sedangkan di MI Hidayatul Mubtadiin Wates Sumbergempol Tulungagung, proses pemanfaatan sumber belajar dalam pengembangan karakter peserta didik di MI Hidayatul Mubtadiin Wates Sumbergempol Tulungagung sifatnya pengkondisian lingkungan sekolah serta pembiasaan yang selalu berakhlakul karimah. Disamping itu rutinitas, spontanitas, keteladanan dan kegiatan terprogram. Kegiatan rutinitas yang dilaksanakan di MI Hidayatul Mubtadiin Wates Sumbergempol Tulungagung.

Mansur Muslich menjelaskan dalam penerapan pendidikan karakter dapat dilakukan dengan berbagai strategi pengintegrasian. Strategi yang dapat dilakukan adalah: ${ }^{17}$ Pengintegrasian dalam kegiatan sehari-hari seperti: (1) Keteladanan guru, Kegiatan ini bisa dilakukan oleh pengawai, kepala sekolah, guru, staf administrasi di sekolah yang dapat dijadikan model bagi peserta didik. (2) Kegiatan spontan,

\footnotetext{
${ }^{16}$ Karti Soeharto, Teknologi Pembelajaran Pendekatan Sistem, Konsepis dan Model, SAP, Evaluasi, Sumber Belajar dan Media, (Surabaya: SIC, 2003), h. 80-82.

${ }^{17}$ Muslich Masnur, Pendidikan Karakter,. h.. 175.
}

Jurnal Dirasah, Volume 1, Nomor 1, Februari 2018 
Kegiatan yang dilakukan secara tiba-tiba pada saat itu juga. (3) Teguran, Guru perlu menegur peserta didik yang melakaukan perilaku buruk dan mengingat agar mengamalakan nilai-nilai yang baik sehingga guru dapat membantu mengubah tingkah laku mereka, (4) Pengkondisian lingkungan, Suasana sekolah dikondisikan sedemikian rupa dengan penyediaan sarana fisik. (5) Kegiatan rutinitas, Kegiatan ini merupakan kegiatan yang dilakukan peserta didik secara terus menerus dan konsistensi setiap saat.

Dalam dunia pendidikan semua mengetahui bahwa tugas guru bukan hanya mengajar dan memberi ilmu pengetahuan saja kepada peserta didik tetapi lebih dari itu, yakni mengembangkan karakter peserta didik sehingga tercapailah kepribadian yang berakhlakul karimah. Bahwasannya tingkah laku seseorang dapat diubah ketika diberi rangsangan-rangsangan, disesuaikan dengan perubahan tingkah laku yang diinginkan.

\section{Hasil sumber belajar dalam pengembangan karakter peserta didik}

Berdasarkan temuan dari penelitian hasil pemanfaatan sumber belajar di MI Nurul Islam dan MI Hidayatul Mubtadiin Wates Sumbergempol Tulungagung dilaksanakan dalam setiap kegiatan mulai dari pembelajaran, saat anak terlibat dalam pengembangan diri, dan ketika anak berada dalam budaya madrasah, namun penilaian itu belum tersusun dengan baik. Dari beberapa karakter yang telah tumbuh di MI Nurul Islam Sumbergempol Tulungagung, seperti religius, disiplin, peduli lingkungan, kreatif, tanggung jawab, gemar membaca. Sedangkan MI Hidayatul Mubtadiin Wates religius, disiplin, bersahabat dan komunikatif, mandiri, jujur, tanggung jawab, dan peduli lingkungan.

Hal serupa juga dialami oleh MI Hidayatul Mubtadiin Wates Sumbergempol Tulungagung dimana pemanfaatan sumber belajar memiliki peranan dalam pengembangan karakter peserta didik, melalui hasil observasi, wawancara maupun dokumentasi yang telah dilakukan oleh peneliti juga menunjukkan bahwa karakter apa saja yang sudah terlihat di MI HIdayatul Mubtadiin Wates Sumbergempol Tulungagung, diantaranya adalah religius, disiplin, bersahabat dan komunikatif, mandiri, jujur, tanggung jawab, dan peduli lingkungan.

Pengembangan karakter dalam suatu sistem pendidikan adalah keterkaitan antara komponen-komponen karakter yang mengandung nilai-nilai perilaku, yang dapat dilakukan atau bertindak secara bertahap dan saling berhubungan antara pengetahuan nilai-nilai perilaku dengan sikap atau emosi yang kuat untuk melaksanakannya, baik terhadap Tuhan YME, dirinya, sesama, lingkungan, bangsa dan negara serta dunia internasional. 
Kebiasaan berbuat baik tidak selalu menjamin bahwa manusia yang telah terbiasa tersebut secara sadar menghargai pentingnya nilai karakter (valuing). Karena mungkin saja perbuatannya tersebut dilandasi oleh rasa takut untuk berbuat salah, bukan karena tingginya penghargaan akan nilai itu. Misalnya ketika seseorang berbuat jujur hal itu dilakukan karena dinilai oleh orang lain, bukan karena keinginannya yang tulus untuk mengharagi nilai kejujuran itu sendiri. ${ }^{18}$

Jadi ada relevensi antara teori dengan kehidupan nyata bahwa melalui pemanfaatan sumber belajar yang berada di sekolah mampu mengembangan karakter peserta didik dengan berbagai macam karakter di MI Nurul Islam Mirigambar dan MI Hidayatul Mubtadiin Wates Sumbergempol Tulungagung.

\section{Kesimpulan Dan Saran}

\section{Kesimpulan}

Berdasarkan hasil penelitian dilapangan yang dilakukan peneliti, maka dapat ditarik kesimpulan sebagai berikut:

1. Cara memilih sumber belajar pada MI Nurul Islam Mirigambar dan MI Hidayatul Mubtadiin Wates Sumbergempol Tulungagung, yaitu dengan menyesuaikan karakter peserta didik, lingkungan sekitar, dan pembiasaan. Pembiasaan yang ditanamkan di lembaga madrasah tersebut adalah yang menjadi sorotan untuk pengembangan karakter peserta didik. Karakter peserta didik yang ada di sekolah, peserta didik lebih suka belajar dengan alam bebas. Lingkungan sekitar adalah keadaan atau suasana yang berada dilingkungan sekolah serta pembiasaan yang di terapkan di sekolah itu apa saja, itu bisa sebagai acuan pemilihan sumber belajar dalam pengembangan karakter peserta didik.

2. Proses pemanfaatan sumber belajar sudah terintegrasikan dalam peraturanperaturan yang telah dibuat oleh lembaga sekolah. Pemanfaatan sumber belajar yang terintegrasi kemudian disosialisasikan dan melaksanakan jadwal kegiatan dengan tertib, serta dibentuknya tim penggerak kegiatan. Pendidikan karakter juga dilaksanakan melalui pengembangan diri yakni tertuang dalam budaya sekolah. Budaya sekolah yang disusun melalui pembiasaan terdiri dari beberapa jenis yaitu bersifat pengkondisian, rutinitas, spontanitas dan keteladanan.

3. Hasil pemanfaatan sumber belajar dilaksanakan dalam setiap kegiatan mulai dari pembelajaran, saat anak terlibat dalam pengembangan diri, dan ketika anak berada dalam budaya madrasah, namun penilaian itu belum tersusun dengan baik. Nilai-

\footnotetext{
${ }^{18}$ Kementerian Pendidikan dan Kebudayaan RI, Pengembangan Pendidikan Budaya dan Karakter Bangsa, (Jakarta: Kementerian Pendidikan Nasional, 2010), h. 10-11.
} 
nilai dari pemanfaatan sumber belajar dalam pengembangan karakter peserta didik dalam kehidupan sehari-hari yang dihasilkan adalah tingkah laku yang telah tumbuh seperti religius, disiplin, peduli lingkungan, tanggung jawab, gemar membaca, kreatif, jujur, mandiri, bersahabat dan komunikatif.

\section{Saran}

Temuan penelitian ini memberikan masukan untuk merancang penelitian berkaitan dengan pemanfaatan sumber belajar dalam pengembangan karakter peserta didik yang belum dijangkau dalam penelitian ini. Terbuka kemungkinan topik yang sama dapat dilakukan dengan pendekatan penelitian yang berbeda, sehingga akan memperkaya khasanah ilmu pengetahuan yang bersumber dari hasil penelitian.

\section{Daftar Pustaka}

Arikunto, Suharsimi. 1993. Prosedur Penelitian, Suatu Pendekatan Praktek, Jakarta: Rineka Cipta.

Dalyono. 2009. Psikologi Pendidikan, Jakarta: Rineka Cipta. . 2003. Evaluasi, Sumber Belajar dan Media, Surabaya: SIC.

Huberman, A Michael and B. Miles Mathew. 1992. Qualitatif Data Analisis, Edisi Bahasa Indonesia. Jakarta:UI Press.

Kementerian Pendidikan dan Kebudayaan RI. 2010. Pengembangan Pendidikan Budaya dan Karakter Bangsa, Jakarta: Kementerian Pendidikan Nasional.

Moleong, Lexy J. 2002. Metodologi Penelitian Kualitatif, Bandung: Remaja Rosda Karya.

Rohani, Ahmad dan Abu Ahmadi. 1991. Pengelolaan Pengajaran. Jakarta: Rineka Cipta.

Sanjaya, Wina. 2009. Perencanaan dan Desain Sistem Pembelajaran, Jakarta: Kencana.

Soeharto, Karti. Teknologi Pembelajaran Pendekatan Sistem, Konsepis dan Model, SAP, 
Sudjana, Nana. 1989. Teknologi Pengajaran, Bandung: Sinar Baru.

Sudjarwo. 1989. Bebererapa Aspek Pengembangan Sumber Belajar, Jakarta: PT Mediyatama Sarana Perkasa.

Sugiyono. 2013. Metode Penelitian Kuantitatif, Kualitatif, dan R\&D. Bandung: Alfabeta.

Ulwan, Abdulloh Nasih. 2005. Belajar dan Pembelajaran. Jakarta: Rineka Cipta.

Undang-undang Sistem Pendidikan Nasional Nomor 20 Tahun 2013 Bandung: Sinar Grafika, 2009

Wijaya, Cece dan A. Thabrani Rusyah.1994. Kemampuan Dasar Guru dalam proses BelajarMengajar, Bandung: Rosda Karya.

Wiriaatmaja, Rochiati. 2007. Metode Penelitian Tindakan Kelas, Bandung: PT. Rosdakarya. 